\title{
Precipitation during El Niño correlates with increasing spread of Phragmites australis in New England, USA, coastal marshes
}

\author{
Todd E. Minchinton*
}

Department of Ecology and Evolutionary Biology, Brown University, Providence, Rhode Island, USA

\begin{abstract}
The grass Phragmites australis has historically been restricted to the relatively benign upper border of coastal marshes, but over the past century, and particularly in recent decades, it has been spreading aggressively in New England throughout brackish and salt marshes with high soil salinities that are physiologically stressful to the plant. Here I tested the hypothesis that variations in climatic conditions, particularly increased precipitation during the 1997-98 El Niño event, buffer harsh abiotic conditions and enhance the performance of this nuisance species. I monitored the growth and reproductive output of $P$. australis in the year before, during, and after the 1997-98 El Niño in coastal brackish marshes of southern New England, USA. During the El Niño year, $P$. australis produced on average $30 \%$ more shoots, which were $25 \%$ taller, and yielded an order of magnitude more inflorescences than in the other 2 years. Soil porewater salinities were negatively related to precipitation during the 3 years of the study, and the growing season during the El Niño year was one of the wettest of the past century. Consequently, increased precipitation during El Niño may facilitate the spread of less salt-tolerant nuisance and invasive species throughout brackish and salt marshes.
\end{abstract}

KEY WORDS: Coastal marshes - El Niño - Global climate change - Invasive species - La Niña · Phragmites australis · Salinity $\cdot$ Temperature

Resale or republication not permitted without written consent of the publisher

Climatic changes associated with the El Niño Southern Oscillation have biological consequences for a diversity of taxa in both marine and terrestrial habitats (Glynn 1990, Dayton et al. 1999, Holmgren et al. 2001). In stressful terrestrial environments such as deserts, seed production, recruitment, and growth of plants have all been linked to variations in rainfall due to El Niño (Holmgren et al. 2001). The impacts of El Niño on

${ }^{*}$ Present address: Department of Environmental Biology, The University of Adelaide, South Australia 5005, Australia. E-mail: todd.minchinton@adelaide.edu.au species in estuarine habitats such as coastal marshes have rarely been investigated, yet plants in these environments, which are characterised by thermal stress and high soil salinity, may be particularly susceptible to climatic extremes.

Over the past century, and particularly in recent decades, the grass Phragmites australis (Cav.) Trin ex Steud (often called 'common reed' and hereafter termed Phragmites) has been aggressively invading coastal marshes of North America, often displacing other marsh plants and forming extensive monospecific stands (Marks et al. 1994, Tiner 1997, Chambers et al. 1999, Meyerson et al. 2000). There is concern that the continued expansion of Phragmites will dramatically alter the structure and function of coastal marsh ecosystems. Historically, $P$. australis has been a minor component of the assemblage of plants along the relatively benign upper border of freshwater and brackish marshes (Niering et al. 1977, Clark 1986, Orson et al. 1987), whereas now it is expanding into more physiologically stressful sectors, including more seaward areas of brackish marshes and along the upper border of salt marshes. One explanation for the recent expansion is that hydrological changes resulting from urban and agricultural development have reduced stressful salinity conditions of the soil, creating an environment suitable for Phragmites (Niering \& Warren 1980, Roman et al. 1984, Hellings \& Gallagher 1992, Chambers et al. 1998, Burdick et al. 2001), although evidence suggests the recent introduction of a non-native genotype morphologically similar to the native Phragmites, but with tolerance to a wider range of environmental conditions (Saltonstall 2002). Whether native or introduced, episodic climatic events such as increased precipitation during El Niño are expected to enhance the growth of Phragmites by reducing salinity stress (Zedler 1983, Allison 1992, 1996). 
Here I report the results of field surveys where I measured the performance of Phragmites in 2 brackish marshes in southern New England, USA, at the end of 3 growing seasons before, during, and after the 1997-98 El Niño event, which was one of the 2 strongest El Niño events of the past century (Wolter \& Timlin 1998). I tested the hypothesis that the vegetative growth and reproductive output of Phragmites is greater in the El Niño year than in the other 2 years, and that these differences are linked to variations in air temperature and precipitation. Results showed that the El Niño year had one of the wettest growing seasons of the past century and a corresponding dramatic increase in the performance of Phragmites. Determining how climatic conditions affect invasive species will help to predict their patterns of spread and interactions with native species.

Methods. I monitored the performance of Phragmites from April 1997 to September 1999 at 2 coastal brackish marshes, one along the Runnins River $\left(41^{\circ} 47^{\prime} \mathrm{N}\right.$, $\left.71^{\circ} 20^{\prime} \mathrm{W}\right)$ in East Providence, Rhode Island, and the other about $4 \mathrm{~km}$ away along the Palmer River $\left(41^{\circ} 47^{\prime} \mathrm{N}\right.$, $\left.71^{\circ} 16^{\prime} \mathrm{W}\right)$ in Rehoboth, Massachusetts. These marshes are located in developed suburban environments, and are comprised of typical plant assemblages of brackish and salt marshes in southern New England (e.g. Niering \& Warren 1980, Tiner 1987). The marshes experience semi-diurnal tides with a maximum range of about $2.4 \mathrm{~m}$, and water salinities vary from 0 to 30 (unpubl. data). Phragmites is a clonal grass with annual shoots and perennial rhizomes that spreads primarily by vegetative growth to form monospecific stands along the upper border of brackish and salt marshes (Haslam 1972, Niering \& Warren 1980, Meyerson et al. 2000). Rhizomes grow primarily during autumn (September to November), and associated buds that give rise to new shoots may develop at almost any time of the year (Haslam 1969a). In southern New England, shoots emerge and grow mainly in spring and early summer (April to June), reach a maximal height and develop inflorescences and seeds at the end of the growing season in late summer or early autumn (August or September), and then senesce (Tiner 1997, Meyerson 2000). While Phragmites is considered a nuisance species in regions of North America (Marks et al. 1994, Tiner 1997, Chambers et al. 1999), it is valued in
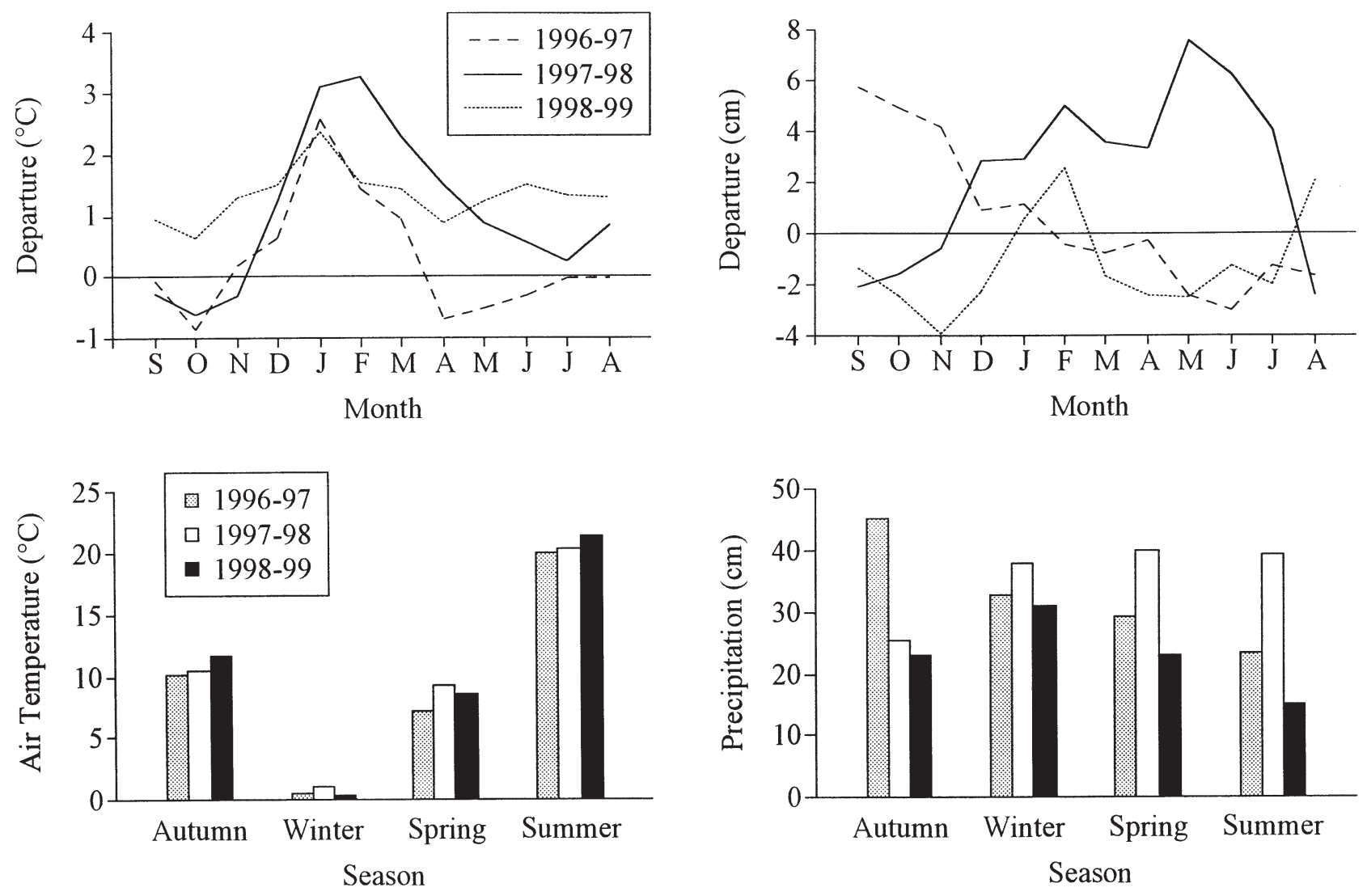

Fig. 1. Temperature and precipitation averages for Rhode Island and Massachusetts in the 1996-97 neutral year, the 1997-98 El Niño year, and the 1998-99 La Niña year. Top: departures from long-term averages for the past 105 years in the monthly means of air temperature (left) and precipitation (right). Bottom: mean air temperatures (left) and total precipitation (right) from autumn (September to November) of one year to the winter (December to February), spring (March to May), and summer (June to August) of the next 
Europe where there is concern over its recent die-back (van der Putten 1997; but see Güsewell \& Klötzli 1998 for concern over the expansion of Phragmites in the fen meadows of Switzlerland).

At the end of the growing seasons of 1997, 1998 and 1999, I quantified the vegetative growth and reproductive output of Phragmites in 3 quadrats randomly located along each of 2 stands at the upper border of each marsh. This yielded a hierarchical sampling design, with 2 stands nested within each of 2 marshes. Quadrats (3 $\mathrm{m}^{2}$ at Runnins, $1.5 \mathrm{~m}^{2}$ at Palmer) were located along the edges of the stands where Phragmites is spreading seaward into the marsh dominated by a mixture of the rush Juncus gerardi and the grasses Spartina patens and Distichlis spicata (Tiner 1987). In each quadrat, I counted the number of shoots that emerged during the growing season and the number with inflorescences, and measured the heights of 20 randomly selected shoots. At roughly monthly intervals during the growing season in all 3 years, I measured soil porewater salinity at the marsh surface (0 to $5 \mathrm{~cm}$ depth) at several sites along the upper border of each marsh using a handheld refractometer. I obtained climatic data from the Northeast Regional Climate Center, National Oceanic and Atmospheric Administration (http://met-www.cit.cornell.edu). Raw data are presented as well as departures (averaged for Rhode Island and Massachusetts) in the monthly means of air temperature and precipitation from long-term averages for the past 105 yr. To highlight seasonal trends, I smoothed the data with a 3 month running mean comprising the month presented and the previous and following months.

Results. Extreme air temperatures and precipitation characterized the 1997-98 El Niño year from winter until early summer (Fig. 1). The winter and spring seasons during El Niño were among the 10 hottest and wettest of the past $105 \mathrm{yr}$. Climatic conditions in 1998-99, which was a La Niña year, were also severe, with above-average air temperatures and belowaverage precipitation (Fig. 1). In contrast to the El Niño year, the spring and summer growing seasons experienced drought, and the summer during La Niña was the third-hottest and eighth-driest of the past $105 \mathrm{yr}$. Climate during 1996-97, which was a neutral year, was less extreme, but still exhibited a wet autumn, a mild winter similar to the El Niño and La Niña years, and a dry spring and summer, as in the La Niña year (Fig. 1). Simple linear regression showed that square-roottransformed estimates of soil porewater salinity (range $=1$ to $39 ;$ median $=17 ;$ mean $\pm \mathrm{SD}=18 \pm 10 ; \mathrm{n}=41$ ) in one month were negatively related to total precipitation $\left(\mathrm{r}^{2}=0.68, \mathrm{p}<0.001, \mathrm{n}=41\right)$ and positively related to average air temperatures $\left(\mathrm{r}^{2}=0.22, \mathrm{p}<0.01, \mathrm{n}=41\right)$ in the previous month.
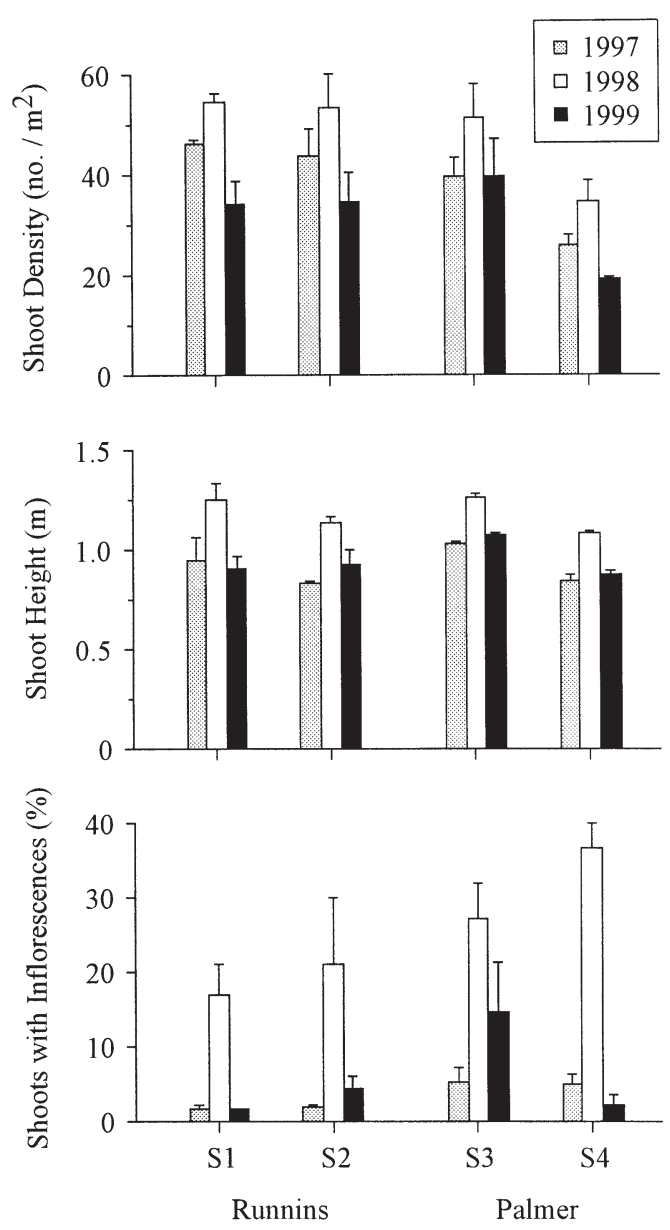

Fig. 2. Phragmites australis. Density, height, and percentage of shoots with inflorescences (means $\pm \mathrm{SE}$ ) at the end of the growing season for each of 2 stands of Phragmites in each of 2 marshes in 1997 (1996-97 neutral year), 1998 (1997-98 El Niño year), and 1999 (1998-99 La Niña year)

Stands of Phragmites produced about $25 \%$ more shoots in 1998 than in 1997, and this density was reduced by about $35 \%$ in 1999 (Fig. 2, Table 1). Shoots in 1998 were on average about $25 \%$ taller than those in 1997 or 1999. Similar to the absolute density of inflorescences (no. $\mathrm{m}^{-2}$ ) produced in each year (1997: $1.3 \pm 0.29 ; 1998: 11.5 \pm 1.11 ; 1999: 1.8 \pm 0.71 ; \mathrm{n}=12$, mean $\pm \mathrm{SE}$ ), the percentage of shoots with inflorescences in 1998 was on average 5 and 7 times greater than those produced in 1999 and 1997, respectively. Differences in the performance of $P$. australis among years were consistent despite variation in the densities and heights of shoots among stands and in the percentage of shoots producing inflorescences between marshes (Fig. 1, Table 1).

Discussion. The performance of Phragmites was linked to climatic variations associated with the El Niño Southern Oscillation. Precipitation, and associated freshwater run-off, appears to be an important 
Table 1. Phragmites australis. ANOVA of shoot density (natural logarithms), height, and percentage with inflorescences at the end of the growing season for each of 2 stands of in each of 2 marshes in 1997 (1996-97 neutral year), 1998 (199798 El Niño year), and 1999 (1998-99 La Niña year). Year is a fixed factor, marsh is a random factor, and stand is a random factor nested within a marsh. Outcomes of Student-Newman-Keuls multiple comparisons tests $\left(\mathrm{SNK}_{i} \mathrm{p}<0.05\right)$ for the effect of year are given in the last row. ns $=$ not significant; ${ }^{*}=\mathrm{p}<0.05_{i}{ }^{* *}=\mathrm{p}<0.001$

\begin{tabular}{|lrrrrrrrr|}
\hline \multirow{2}{*}{ Source } & \multirow{2}{*}{ df } & \multicolumn{2}{c}{ Density } & \multicolumn{2}{c|}{ Height } & \multicolumn{2}{c|}{ Inflorescences } \\
& & MS & $F$ & \multicolumn{1}{c}{ MS } & $F$ & MS & \multicolumn{1}{c}{$F$} \\
\hline Year: Y & 2 & 0.605 & $42.4^{*}$ & 2525.0 & $51.25^{*}$ & 1744.9 & $23.64^{*}$ \\
Marsh: M & 1 & 0.645 & $1.13 \mathrm{~ns}$ & 57.3 & $0.06 \mathrm{~ns}$ & 474.7 & $30.73^{*}$ \\
Stand (M): S(M) & 2 & 0.570 & $13.25^{* * *}$ & 881.5 & $10.70^{* * *}$ & 15.4 & $0.35 \mathrm{~ns}$ \\
Y $\times$ M & 2 & 0.014 & $0.61 \mathrm{~ns}$ & 49.3 & $1.10 \mathrm{~ns}$ & 73.8 & $0.80 \mathrm{~ns}$ \\
Y $\times$ S(M) & 4 & 0.023 & $0.55 \mathrm{~ns}$ & 44.8 & $0.54 \mathrm{~ns}$ & 92.5 & $2.10 \mathrm{~ns}$ \\
Residual & 24 & 0.043 & & 82.4 & & 44.1 & \\
SNK for year & \multicolumn{3}{c}{$98>97>99$} & $98>99=97$ & $98>99=97$ \\
\hline
\end{tabular}

climatic parameter influencing the spread of Phragmites because production (i.e. density and height of shoots) and reproductive output were greater during the extremely wet El Niño year than during the other 2 years, which were characterized by dry conditions, particularly the La Niña year when there was drought. The strong negative relationship between precipitation and soil salinity suggests that the increased performance of Phragmites during the wet El Niño year might have been due to freshwater input ameliorating stressful salinity conditions, which have been observed to reduce the growth of Phragmites (Hellings \& Gallagher 1992, Lissner \& Schierup 1997, Chambers et al. 1998, Burdick et al. 2001). Other correlated factors that might also affect the growth of Phragmites, such as increased sedimentation due to freshwater run-off, cannot be ruled out (Allison 1996). The spring and summer growing season, rather than autumn when rhizome extension and bud formation occurs, appears to be the critical period when climatic conditions affect the performance of Phragmites (Zemlin et al. 2000). A warm and wet winter may also promote the emergence and growth of $P$. australis, but all 3 winters were extremely mild, so this is difficult to ascertain. In contrast, air temperatures were positively related to soil salinity and, therefore, the high air temperatures during the growing season of the El Niño and La Niña years might have reduced the performance of Phragmites by increasing evaporation and, consequently, soil salinity. In more freshwater habitats, high air temperatures have been shown to increase the growth of Phragmites (Haslam 1969b, Zemlin et al. 2000). The influence of air temperature on Phragmites may, therefore, be positive when accompanied by heavy precipitation, as in the El Niño year, and negative during drought conditions, as in the La Niña year.
Climate change, particularly increased precipitation due to El Niño, is unlikely to be the cause of the recent expansion of Phragmites throughout North American marshes. The widespread invasion of Phragmites may be due to a new, introduced genotype, which is likely to be prevalent in southern New England (Saltonstall 2002). Nevertheless, results here indicate that, whatever the cause, increased precipitation during El Niño may further accelerate the regional spread of Phragmites. Although this study was only done over 3 years surrounding a single El Niño event, the strong differences in climatic conditions among years (particularly the levels of precipitation between the El Niño year and the other 2 years) and the corresponding dramatic changes in the performance of Phragmites present strong evidence for a link between El Niño, precipitation, and the spread of Phragmites. Indeed, the performance of Phragmites was consistent across stands separated by tens to hundreds of metres and marshes separated by kilometres, suggesting a regional effect of climate. Climatic variations appear to contribute to the regional expansion of this nuisance species by increasing the probability that wind-dispersed seeds will colonise neighbouring marshes and that vegetatively expanding shoots will displace existing marsh plants. Therefore, climate may alter the intensity of ecological interactions between native and invasive species (Bertness \& Ewanchuk 2002). With the increase in the frequency, strength, and duration of El Niño events in recent, and perhaps coming, decades (Trenberth \& Hoar 1996, Fedorov \& Philander 2000), a shift in the species composition of coastal marshes from diverse assemblages to monospecific stands of $P$. australis may arrive sooner than anticipated (Chambers et al. 1999, Windham \& Lathrop 1999, Keller 2000, Meyerson et al. 2000).

Precipitation and freshwater pulses, such as those during El Niño, have a regional influence on the demography of plants in terrestrial habitats (Holmgren et al. 2001) and can influence the assemblage structure of plants in salt marshes (Zedler 1983, Allison 1992, 1996). Brackish and salt marshes may be particularly susceptible to invasion by less salt-tolerant nuisance and invasive species during El Niño or other episodic climate events (Zedler 1983, Allison 1992, 1996, Dukes $\&$ Mooney 1999). At these times, managers of coastal marshes should be particularly vigilant in their efforts to detect colonisation by such species. Determining how changes in the demography of invasive species and their ecological interactions with other members of 
the species assemblage are affected by these climatic episodes may not only help in the management and control of problem species, but may also provide a window of insight into the future consequences of global climate change.

Acknowledgements. Thanks to J. Simpson and B. Tavani for assistance in the field and to M. Bertness for support and encouragement at all stages of the research. The Rhode Island Sea Grant College Program, the A. W. Mellon Foundation, and the Natural Sciences and Engineering Research Council of Canada funded the research.

\section{LITERATURE CITED}

Allison SK (1992) The influence of rainfall variability on the species composition of a northern California salt marsh assemblage. Vegetatio 101:145-160

Allison SK (1996) Recruitment and establishment of salt marsh plants following disturbance by flooding. Am Midl Nat 136:232-247

Bertness MD, Ewanchuk PJ (2002) Latitudinal and climatedriven variation in the strength and nature of biological interactions. Oecologia 132:392-401

Burdick DM, Buchsbaum R, Holt E (2001) Variation in soil salinity associated with expansion of Phragmites australis in salt marshes. Environ Exp Bot 46:247-261

Chambers RM, Mozder TJ, Ambrose JC (1998) Effects of salinity and sulfide on the distribution of Phragmites australis and Spartina alterniflora in a tidal saltmarsh. Aquat Bot 62:161-169

Chambers RM, Meyerson LM, Saltonstall K (1999) Expansion of Phragmites australis into tidal wetlands of North America. Aquat Bot 64:261-273

Clark JS (1986) Late-holocene vegetation and coastal processes at a Long Island tidal marsh. J Ecol 74:561-578

Dayton PK, Tegner MJ, Edwards PB, Riser KL (1999) Temporal and spatial scales of kelp demography: the role of oceanographic climate. Ecol Monogr 69:219-250

Dukes JS, Mooney HA (1999) Does global change increase the success of biological invaders? Trends Ecol Evol 14: 135-139

Fedorov AV, Philander SG (2000) Is El Niño changing? Science 288:1997-2002

Glynn PW (1990) Global ecological consequences of the 1982-1983 El Niño-Southern Oscillation. Elsevier, Amsterdam

Güsewell S, Klötzli F (1998) Abundance of common reed (Phragmites australis), site conditions and conservation value of fen meadows in Switzerland. Acta Bot Neerl 47:113-129

Haslam SM (1969a) The development and emergence of buds in Phragmites communis Trin. Ann Bot 33:289-301

Haslam SM (1969b) The development of shoots in Phragmites communis Trin. Ann Bot 33:695-709

Haslam SM (1972) Biological flora of the British Isles: Phragmites communis Trin. J Ecol 60:585-610

Editorial responsibility: Charles Peterson (Contributing

Editor), Morehead City, North Carolina, USA
Hellings SE, Gallagher JL (1992) The effects of salinity and flooding on Phragmites australis. J Appl Ecol 29: $41-49$

Holmgren M, Scheffer M, Ezcurra E, Gutiérrez JR, Mohren GMJ (2001) El Niño effects on the dynamics of terrestrial ecosystems. Trends Ecol Evol 16:89-94

Keller BEM (2000) Plant diversity in Lythrum, Phragmites, and Typha marshes, Massachusetts, U.S.A. Wetlands Ecol Manag 8:391-401

Lissner J, Schierup HH (1997) Effects of salinity on the growth of Phragmites australis. Aquat Bot 55:247-260

Marks M, Lapin B, Randall J (1994) Phragmites australis (P. communis): threats, management, and monitoring. Nat Areas J 14:285-294

Meyerson LA, Saltonstall K, Windham L, Kiviat E, Findlay S (2000) A comparison of Phragmites australis in freshwater and brackish marsh environments in North America. Wetlands Ecol Manag 8:89-103

Niering WA, Warren RS (1980) Vegetation patterns and processes in New England Salt Marshes. BioScience 30: 301-307

Niering WA, Warren RS, Weymouth CG (1977) Our dynamic tidal marshes: vegetation changes as revealed by peat analysis. Connecticut Arboretum Bull 22

Orson RA, Warren RS, Niering WA (1987) Development of a tidal marsh in a New England river valley. Estuaries 10:20-27

Roman CT, Niering WA, Warren RS (1984) Salt marsh vegetation change in response to tidal constriction. Environ Manag 8:141-150

Saltonstall K (2002) Cryptic invasion by a non-native genotype of the common reed, Phragmites australis, into North America. Proc Natl Acad Sci USA 99:2445-2449

Tiner R (1997) Managing common reed (Phragmites australis) in Massachusetts: an overview of the species and control techniques. Massachusetts Wetlands Restoration and Banking Program, Boston

Tiner RW Jr (1987) A field guide to coastal wetland plants of the northeastern United States. The University of Massachusetts Press, Amherst

Trenberth KE, Hoar TJ (1996) The 1990-1995 El Niño-Southern Oscillation event: longest on record. Geophys Res Lett 23:57-60

van der Putten WH (1997) Die-back of Phragmites australis in European wetlands: an overview of the European Research Programme on Reed Die-back and Progression. Aquat Bot 59:263-275

Windham L, Lathrop RG Jr (1999) Effects of Phragmites australis (common reed) invasion on aboveground biomass and soil properties in brackish tidal marsh of the Mullica River, New Jersey. Estuaries 22:927-935

Wolter K, Timlin MS (1998) Measuring the strength of ENSO events: how does 1997/98 rank? Weather 53:315-324

Zedler JB (1983) Freshwater impacts in normally hypersaline marshes. Estuaries 6:346-355

Zemlin R, Kühl H, Kohl JG (2000) Effects of seasonal temperature on shoot growth dynamics and shoot morphology of common reed (Phragmites australis). Wetlands Ecol Manag 8:447-457

Submitted: April 16, 2002 ; Accepted: July 2, 2002

Proofs received from author(s): October 12, 2002 